\title{
Novel Biologically Active Peptides from the Venom of Polistes rothneyi iwatai
}

\author{
Kazuya Murata, ${ }^{a}$ Tetsuro Shinada, ${ }^{*, a}$ Yasufumi Ohfune, ${ }^{*, a}$ Miki Hisada, ${ }^{b}$ Akikazu Yasuda, ${ }^{b}$ \\ Hideo NAOKI, ${ }^{b}$ and Terumi NAKAJIMA ${ }^{b}$ \\ ${ }^{a}$ Graduate School of Science, Osaka City University; 3-3-138 Sugimoto, Sumiyoshi-ku, Osaka 558-8585, Japan: and \\ ${ }^{b}$ Suntory Institute for Bioorganic Research; 1-1-1 Wakayamadai, Shimamoto-cho, Mishima-gun, Osaka 618-8503, Japan. \\ Received August 25, 2006; accepted September 30, 2006; published online October 4, 2006
}

\begin{abstract}
Four novel peptides, polistes-mastoparan-R1, 2, 3, and polistes-protonectin, were isolated from the venom of a paper wasp, Polistes rothneyi iwatai. MALDI-TOF MS analysis of a small amount of the crude venom gave six molecular-related ion peaks. Among them, $m / z 1565$ was expected to be a novel peptide. Purification of the crude venom by HPLC gave two known kinins, Thr ${ }^{6}$-bradykinin and Ala-Arg-Thr ${ }^{6}$-bradykinin, and four novel peptides named polistes-mastoparan-R1, 2, and 3, and polistes-protonectin. Polistes-mastoparan-R1, 2, and 3 (Pm-R) were tetradecapeptides that possess high sequence homology with that of mastoparan. The sequence of polistesprotonectin was similar to that of protonectin isolated from a Brazilian paper wasp. Histamine-releasing activities of Pm-R1, 2, and 3 were more potent than that of mastoparan. Polistes-protonectin exhibited the most potent hemolytic activity in comparison with the four novel peptides and mastoparan.
\end{abstract}

Key words venom; wasp; polistes-mastoparan; polistes-protonectin; heamolytic acitivity; histamine-releasing activity

The venom of honeybees, hornets, and yellow jackets contain various pharmacologically active peptides, ${ }^{1-5)}$ e.g., mast cell degranulating peptides (mastoparans), ${ }^{2-5,6)}$ kinins (vespakinins and polisteskinins), ${ }^{7-9)}$ hemolytic peptide (melittin), ${ }^{10)}$ neurotoxic peptide (apamin), ${ }^{11)}$ and chemotactic peptides. $^{2-5)}$ The social wasp subfamily Polistinae is a kind of dangerous social wasp the same as hornets and yellow jackets. Wasp kinins and mastoparan analogs known as pain-producing and histamine-releasing peptides have been isolated from the venom of Polistinae..$^{2-4,12,13)}$ Watanabe and coworkers found $\mathrm{Thr}^{6}$-bradykinin and Ala-Arg-Thr ${ }^{6}$-bradykinin in the venom of Polistes rothneyi iwatai. They also mentioned that several peptides have remained unidentified in this venom. These facts prompted us to investigate the structurally unknown peptides in the venom of Polistes rothneyi iwatai based on the MS analysis-guided peptide search using MALDI-TOF MS and ESI/MS analysis. ${ }^{14-20)}$ Herein, we report four novel biologically active peptides in the venom of Polistes rothneyi iwatai and their histamine-releasing and hemolytic activities.

\section{MATERIALS AND METHODS}

Sample Preparation The female wasps of $P$. rothneyi iwatai were collected in Kisaichi, Osaka, frozen in liquid nitrogen, and kept at $-75^{\circ} \mathrm{C}$. The venom sacs were dissected after thawing, lyophilized, and extracted with $\mathrm{MeCN} / \mathrm{H}_{2} \mathrm{O}$ (1/1). The extract was subjected to Zip-Tip ${ }^{\mathrm{TM}} \mathrm{Ax}$ and Zip$\mathrm{Tip}^{\mathrm{TM}} \mathrm{C} 18$ to provide a crude sample.

MALDI-TOF MS and ESI MS Analysis The matrixassisted laser desorption/ionization time-of-flight (MALDITOF) mass spectrum (MS) was acquired on a Voyager Elite MALDI-TOF MS (PerSeptive Biosystems, Foster City, CA, U.S.A.) equipped with a delayed extraction source and $337 \mathrm{~nm}$ pulsed laser. $\alpha$-CHCA ( $\alpha$-cyano-4-hydroxy cinnamic acid) was used as a matrix for MALDI-TOF MS. Collisioninduced dissociation (CID)/post source decay (PSD) analysis was performed with the Voyager Elite MALDI-TOF MS under the conditions as follows: collision gas, argon; accelerating voltage $20 \mathrm{kV}$. The Nanoflow electrospray ionizationquadraple orthogonal acceleration (ESI-Q)-TOF MS and MS/MS (Micromass, Manchester, U.K.) were performed under the conditions as follows: capillary voltage, $1800 \mathrm{~V}$, cone voltage, $50 \mathrm{~V}$; collision gas, argon; collision energy $35 \mathrm{~V}$. The molecular-related ions were detected using positive mode by MALDI-TOF MS and nanoflow ESI-Q-TOF MS.

HPLC Analysis The crude sample was purified by HPLC with Waters Alliance 2690 system (Waters Milford, MA, U.S.A.) with photodiode array detector under following conditions: column, Tosoh TSKgel ODS 120T $(4.6 \mathrm{~mm}$ i.d. $\times 250 \mathrm{~mm})$; mobile phase, $15 \%$ aq. $\mathrm{MeCN}(0.1 \%$ TFA)-MeCN (0.1\% TFA) in 40 min with linear gradient; flow rate, $1 \mathrm{ml} / \mathrm{min}$.

Peptide Sequencing and Synthesis Amino acid sequence analysis was performed by automated Edman degradation on a protein sequencer (PSQ-1, protein sequencer, Shimadzu, Kyoto, Japan). Digestion with lysyl endopeptidase (Wako, Osaka, Japan) was performed using excess peptides $(0.1 \mu \mathrm{g} / \mathrm{ml})$ in $0.2 \mathrm{M}$ ammonium bicarbonate, $\mathrm{pH} 8.0$, at $37^{\circ} \mathrm{C}$, for $6 \mathrm{~h}$. The resulting digest was subjected to MALDTOF MS and the sequencer after HPLC purification. Amino acid analysis was performed by the AccQ Tag ${ }^{\mathrm{TM}}$ (Waters, Japan) followed by HPLC analysis. Peptides were synthesized with an automated solid-phase peptide synthesizer (Model 433-A, Applied Biosystems, Tokyo Japan) based on the Fmoc strategy and purified on a C18-RP HPLC column under the similar conditions as described in the purification of peptides. Their retention times, molecular-related ions $(\mathrm{m} / \mathrm{z})$, and fragment patterns in MS/MS analysis were identical with those of natural peptides.

Histamine-Releasing Assay ${ }^{21)}$ Histamine-releasing activities of the synthetic peptides were tested using mast cell solutions $\left(10^{5}\right.$ cells $\left./ \mathrm{ml}\right)$ from rat. The peptides and mast cell solutions were incubated at $37^{\circ} \mathrm{C}$ for $10 \mathrm{~min}$. The mixture was centrifuged at $1500 \mathrm{rpm}$ for $10 \mathrm{~min}$. The histamine concentrations in supernatant $(0.1 \mathrm{ml})$ were quantified with 
ELISA kit (Immunotech, Beckman Coulter Company, France). The complete histamine release was estimated with the mast cell lysate prepared by freezing and thawing. Each plot represents the average of duplicate tests. $\mathrm{EC}_{50}$ was calculated from Hill's plot analysis.

Hemolytic Activity Test ${ }^{22}$ The synthetic peptides were incubated with $0.2 \mathrm{ml}$ of sheep blood cells solution $(1 \%$ in $0.85 \% \mathrm{NaCl}$ ) for $1 \mathrm{~h}$ at $40{ }^{\circ} \mathrm{C}$. The solution was centrifuged at $2000 \mathrm{rpm}$ for $10 \mathrm{~min}$. Optical density of the supernatant $(0.1 \mathrm{ml})$ was measured at $550 \mathrm{~nm}$ on a microplate reader (BIO-RAD, Model 450). The complete hemolysis was estimated with $500 \mu \mathrm{g} / \mathrm{ml}$ of saponin. Values indicate the average of three tests.

\section{RRESULT}

A small amount of the crude extract $(1 / 100$ of the 10 venom sacs of Polistes rothneyi iwatai) was subjected to MALDI-TOF MS analysis to provide a peptide mapping in the crude venom. ${ }^{14-20)}$ Six molecular-related ions $\left([\mathrm{M}+\mathrm{H}]^{+}\right)$ at $m / z 104.1,112.1,146.1,1074.4,1301.5$, and 1565.8 were detected (Fig. 1). Peptide database search indicated a possibility that an $[\mathrm{M}+\mathrm{H}]^{+}$ion observed at $m / z 1565.8$ would be assigned to a novel peptide. $[\mathrm{M}+\mathrm{H}]^{+}$ions observed at $\mathrm{m} / \mathrm{z}$ 104.1, 112.1, and 146.1 were assumed to be GABA, histamine, and acetylcholine, respectively. These molecules were identified by LC/ESI-MS analysis developed by us. ${ }^{23,24)}$ According to the report by Watanabe, ${ }^{13)}[\mathrm{M}+\mathrm{H}]^{+}$ions observed at $\mathrm{m} / \mathrm{z} \quad 1074.4$ and 1301.5 would be assigned to $\mathrm{Thr}^{6}$ bradykinin (M.W. 1073.6) and Ala-Arg-Thr'-bradykinin (M.W. 1300.7), respectively.

MS analysis-guided peptide search of the crude venom indicated that the peptide in the venom would be novel. On the basis of this observation, we next purified the crude venom

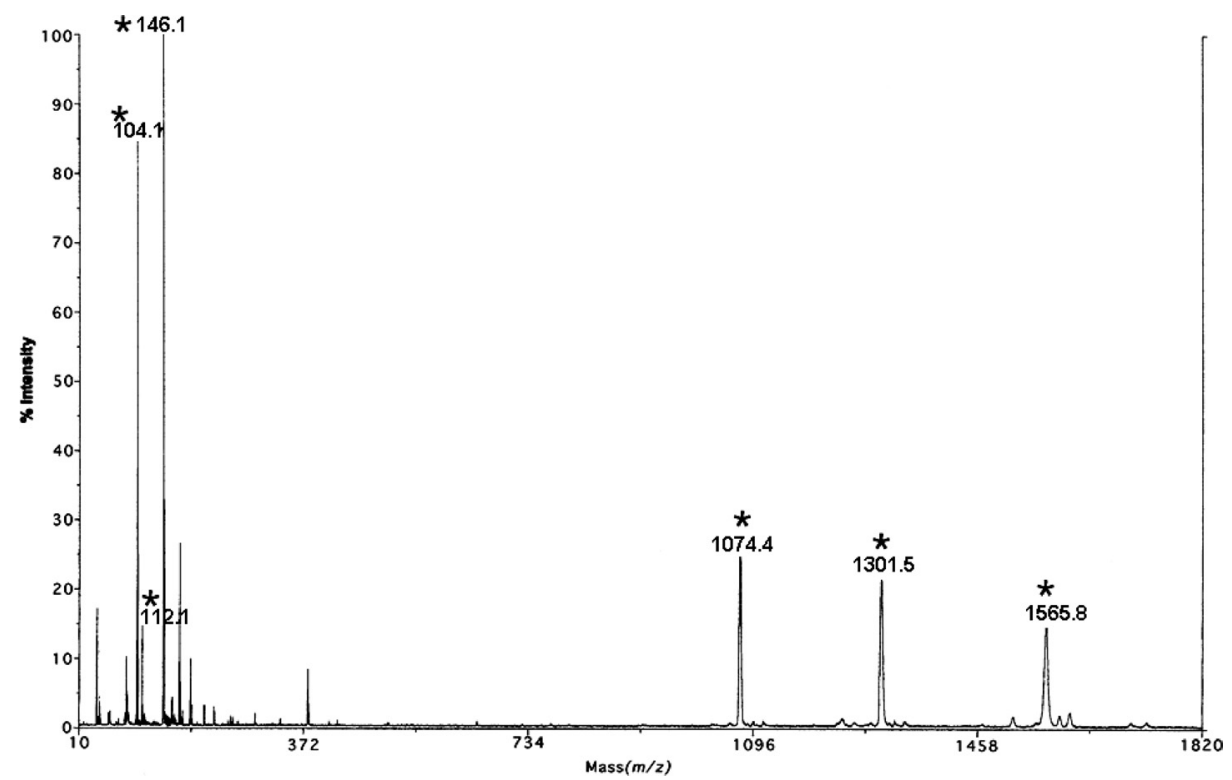

Fig. 1. MALDI-TOF MS Spectrum of the Crude Venom Extract of P. rothneyi iwatai

An aliquot of extract was subjected onto MALDI stainless plate. The same volume of $\alpha \mathrm{CHCA}$ in $50 \%$ aq. MeCN $(0.1 \%$ TFA) was overlaid and dried in vacuo. The spectrum was obtained with Voyager-Elite (Applied Biosystems, Foster City, CA, U.S.A.) with linear mode. Asterisks $(*)$ show the molecular-related ion peaks, which are distinguishable from those derived from matrix.

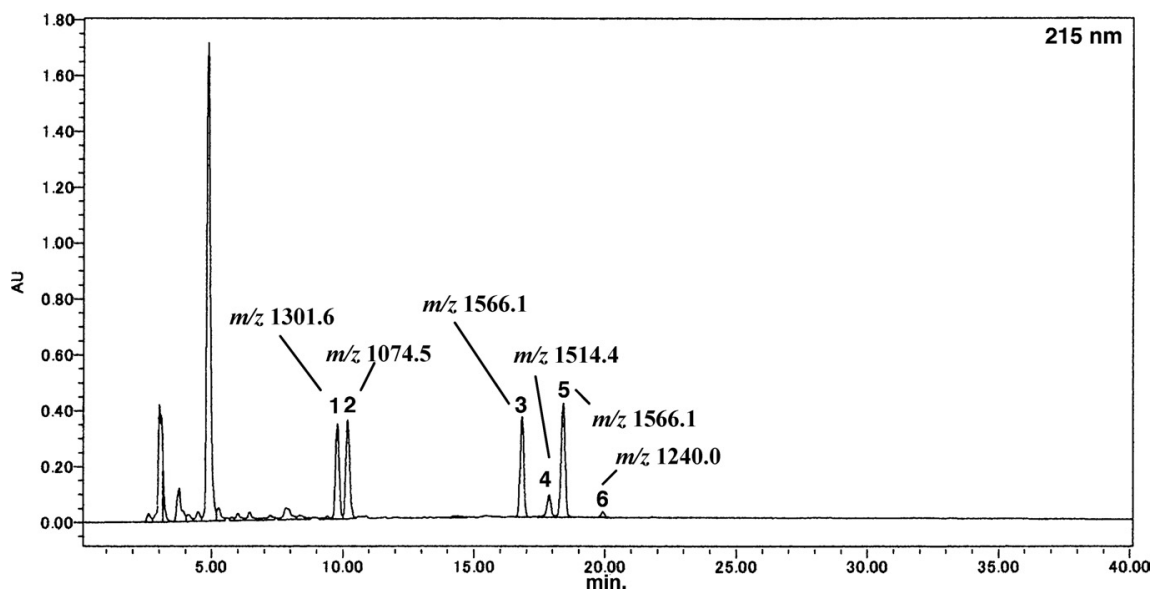

Fig. 2. HPLC Analysis of the Crude Venom Extract of $P$. rothneyi iwatai (UV $215 \mathrm{~nm}$ )

HPLC was performed with Waters Alliance 2690 system with a photodiode array detector. HPLC conditions: column, Tosoh TSKgel ODS $120 \mathrm{~T}(4.6$ i.d. $\times 250$ mm); mobile phase $(15 \%$ aq. $\mathrm{MeCN}(0.1 \%$ TFA $)-\mathrm{MeCN}(0.1 \%$ TFA $)$ in 40 min with linear gradient; flow rate, $1 \mathrm{ml} / \mathrm{min}$. Numbers show the molecular-related ion peaks $(\mathrm{m} / \mathrm{z})$ observed in MALDI-TOF MS. 


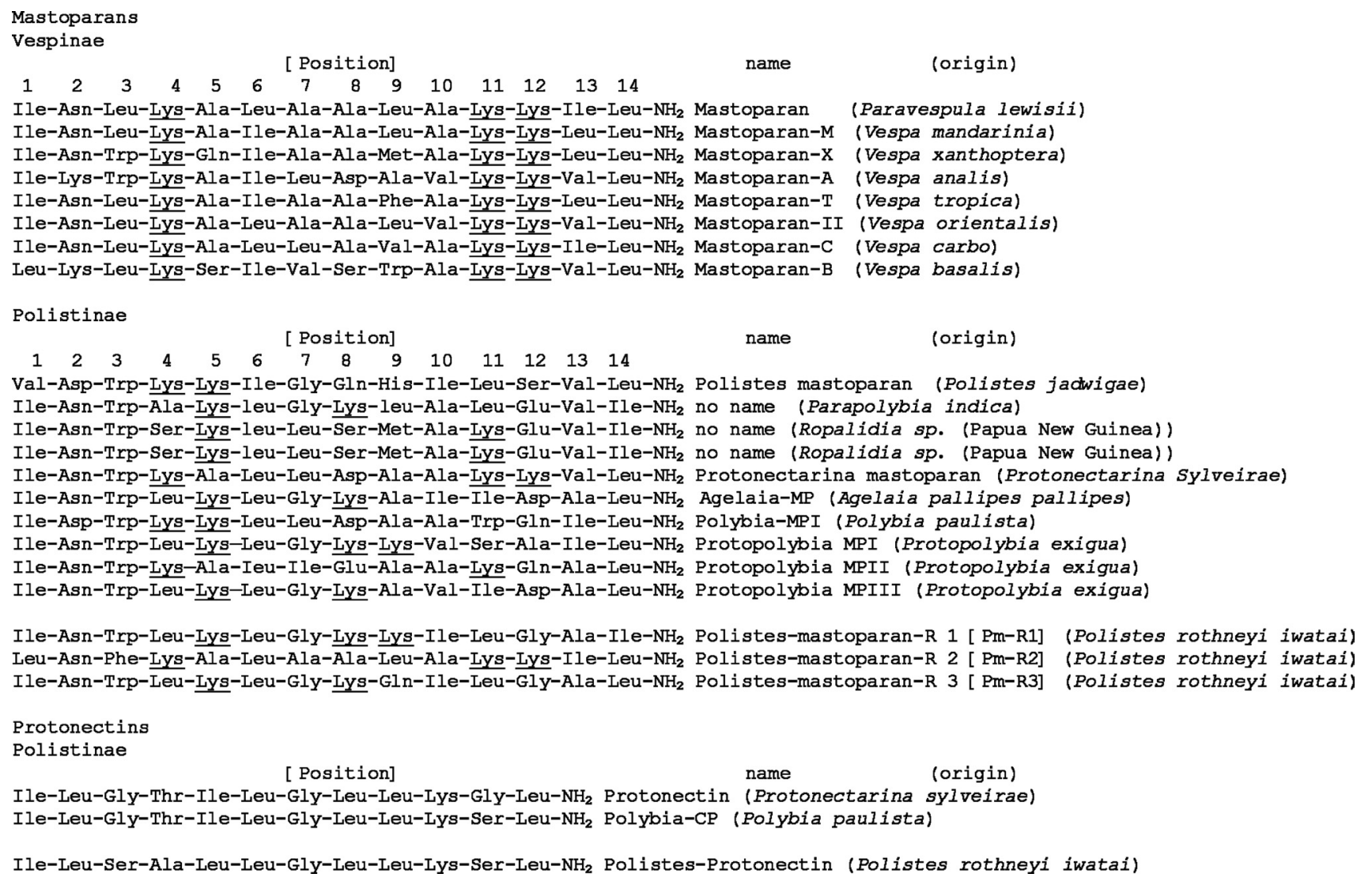

Fig. 3. Amino Acid Sequence of Mastoparans and Protonectins in the Venom of Vespinae and Polistinae

mixture by HPLC to give six fractions (P-1 to P-6) (Fig. 2). MALDI-TOF MS analysis of these fractions gave $[\mathrm{M}+\mathrm{H}]^{+}$ ion peaks at $\mathrm{m} / \mathrm{z} 1301.6,1074.5,1566.1,1514.4,1566.1$, and 1240.0, respectively. Peptide sequences of P-1, 2, 4, and 6 were determined by automated Edman degradation (Fig. 3). P-1 $(m / z$ 1301.6) and P-2 $(m / z$ 1074.5) were identified to AlaArg-Thr'-bradykinin and $\mathrm{Thr}^{6}$-bradykinin, ${ }^{13)}$ respectively. MALDI-PSD-TOF MS analysis of P-4 and P-6 gave ion peaks at $m / z 1495.7(-17 \mathrm{mu})$, and $m / z 1222.9$ ( $-17 \mathrm{mu})$, respectively. These results suggested that the $\mathrm{C}$ terminals of $\mathrm{P}$ 4 and P-6 are amidated. P-4 (Pm-R2) and P-6 (polistes protonectin) are novel peptides that show sequence similarity to mastoparan and protonectin, ${ }^{25,26)}$ respectively. Peptide sequences of P-1, P-2, P-4, and P-6 were confirmed by comparison of their retention time and MS/MS patterns with those of synthetic or authentic samples.

MALDI-TOF analysis of P-3 and P-5 gave similar $[\mathrm{M}+\mathrm{H}]^{+}$ion peaks at $\mathrm{m} / \mathrm{z} 1566.1$ and 1566.1 , respectively. These results indicated that the $[\mathrm{M}+\mathrm{H}]^{+}$ion $(\mathrm{m} / \mathrm{z}$ 1565.8) observed in the crude venom analysis by MALDI-TOF MS consisted of P-3 and P-5. MALDI-PSD-TOF MS analysis of $\mathrm{P}-3$ and $\mathrm{P}-5$ gave the corresponding fragment ions $(-17 \mathrm{mu})$, respectively, suggesting that the $\mathrm{C}$ terminals of P-3 and P-5 were amidated. Automated Edman degradation of P-3 provided a partial sequence as Ile-Asn-Trp-Leu-Lys-Leu-GlyLys-Lys-Ile-Leu-X (X indicates unidentified residues) because of the hydrohobicity that caused excessive losses of the extraction steps during the Edman procedure. MALDI-PSDTOF MS analysis of P-3 gave fragment ions ( $b$-series) at $\mathrm{m} / z$ 1549.0, 1436.8, 1364.7, 1307.7, 1194.6, 1081.7, and 953.7. The difference between each fragment ion corresponded to
$\mathrm{X}-\mathrm{Gln} / \mathrm{Lys}-\mathrm{Ile} / \mathrm{Leu}-\mathrm{Ile} / \mathrm{Leu}-\mathrm{Gly}-\mathrm{Ala}-\mathrm{Ile} / \mathrm{Leu}-\mathrm{NH}_{2}$. Edman degradation and MALDI-PSD-TOF MS analysis indicated two possible sequences of P-3 as Ile-Asn-Trp-Leu-Lys-LeuGly-Lys-Lys-Ile-Leu-Gly-Ala-Leu/Ile- $\mathrm{NH}_{2}$. The C-terminal residue (Leu or Ile) was confirmed by amino acid analysis as Ile. Thus, the sequence of P-3 was determined as Ile-AsnTrp-Leu-Lys-Leu-Gly-Lys-Lys-Ile-Leu-Gly-Ala-Ile- $\mathrm{NH}_{2}$ (Pm-R1).

The $[\mathrm{M}+\mathrm{H}]^{+}$ion of $\mathrm{P}-5$ is similar to that of $\mathrm{P}-3$. In addition, ESI-TOF MS/MS and MALDI-PSD-TOF MS analysis of P-5 afforded almost the same fragment patterns to those of $\mathrm{P}-3$. These results suggested that a Lys residue $(5,8$, or 9 position) in P-3 would be replaced to a Gln residue in the sequence of P-5. Automated Edman degradation of P-5 gave a partial sequence of Ile-Asn-Trp-Leu-Lys-Leu-Gly-X- in a similar manner to the case of P-3. MALDI-PSD-TOF MS of P-5 gave fragment ions ( $b$-series) at $\mathrm{m} / z$ 1549.1, 1436.1, 1364.6, 1307.7, 1194.5, and 1081.5, indicating a partial sequence from the C-terminal as -Ile/Leu-Ile/Leu-Gly-AlaIle/Leu- $\mathrm{NH}_{2}$. Since P-5 was expected to be a tetradecapeptide due to the spectral analogy of P-5 to P-3 in the MALDITOF MS and ESI-TOF MS/MS analysis, $\mathrm{X}$ would consist of two unknown residues $\left(-\mathrm{X}_{1}-\mathrm{X}_{2}-\right)$ between the partial fragments. Amino acid analysis of $\mathrm{P}-5$ provided two possible sequences for "- $\mathrm{X}_{1}-\mathrm{X}_{2}-$ " as -Gln-Lys- or -Lys-Gln-. To clarify the possibility, P-5 was digested with lysylendopeptidase and the resulting peptides were subjected to ESI-Q-TOF MS to give $[\mathrm{M}+\mathrm{H}]^{+}$at $m / z 613.4$, suggesting the sequence as -LysGln-. The Ile/Leu residue at the 10,11 , and 14 position was determined by automated Edman degradation of the digest peptides (M.W. 612.4) after HPLC purification. As a result, 
Table 1. Biological Activities of Pm-R1-3 and Polistes-Protonectin

\begin{tabular}{|c|c|c|}
\hline Peptide & $\begin{array}{l}\left.\text { Hemolytic activity }^{a}\right) \\
\text { (at } 50 \mathrm{~mm}, \%)\end{array}$ & $\begin{array}{l}\text { Histamnine-releasing activity }{ }^{b)} \\
\qquad\left(\mathrm{EC}_{50}, \mathrm{mM}\right)\end{array}$ \\
\hline Pm-R1 & 24 & 0.09 \\
\hline Pm-R2 & 23 & 0.26 \\
\hline Pm-R3 & 36 & 0.16 \\
\hline Polistes-protonectin & 97 & - \\
\hline Mastparan & 18 & 0.24 \\
\hline
\end{tabular}

a) A solution of mast cells $\left(10^{5}\right.$ cells $\left./ \mathrm{ml}\right)$ was incubated with peptides at $37^{\circ} \mathrm{C}$ for $10 \mathrm{~min}$. The mixture was centrifuged at $1500 \mathrm{rpm}$ for $10 \mathrm{~min}$. Histamine concentrations of the supernatants $(0.1 \mathrm{ml})$ were quantified with ELISA kit (Immunotech a Beckman Coulter Company, France). The complete histamine release was estimated with the mast cell lysate prepared by freezing and thawing. Each plot represents the average of duplicate test. $\mathrm{EC}_{50}$ values were calculated from Hill's plot. b) Hemolytic activities of peptides. A solution of sheep blood cells $(1 \%$ in $0.85 \% \mathrm{NaCl}, 0.2 \mathrm{ml})$ was incubated with peptides for $1 \mathrm{~h}$ at $40{ }^{\circ} \mathrm{C}$. The mixture was centrifuged at $2000 \mathrm{rpm}$ for $10 \mathrm{~min}$. Optical density of the supernatant $(0.1 \mathrm{ml})$ was measured at $550 \mathrm{~nm}$. The complete hemolysis was estimated with $500 \mu \mathrm{g} / \mathrm{ml}$ of saponin. Values indicate the average of three tests.

the sequence of P-5 was determined to be Ile-Asn-Trp-LeuLys-Leu-Gly-Lys-Gln-Ile-Leu-Gly-Ala-Leu-NH 2 (Pm-R3).

Histamine-releasing activity test using rat mast cells of novel tetradecapeptides P-3 to 5 (Pm-R1-3) was examined (Fig. 3). The potency of Pm-R2 $\left(\mathrm{EC}_{50}=0.26 \mu \mathrm{M}\right)$ was compatible with that of mastoparan $\left(\mathrm{EC}_{50}=0.24 \mu \mathrm{M}\right)$. In contrast, Pm-R1 and $3\left(\mathrm{EC}_{50}=0.09,0.16 \mu \mathrm{M}\right)$ showed more potent activities than that of mastoparan $\left(\mathrm{EC}_{50}=0.24 \mu \mathrm{M}\right)$. Hemolytic activities of $\mathrm{Pm}-\mathrm{R} 1-3$, polistes-protonectin, and mastoparan against sheep blood cells were tested at the concentration of $50 \mu \mathrm{M}$ (Fig. 3). The biological activities of the novel peptides were more potent $[24 \%$ (Pm-R1), 23\% (Pm-R2), 36\% (Pm-R3), and 97\% (polistes-protonectin)] than that of mastoparan (18\%).

\section{DISCUSSION}

MALDI-TOF MS and ESI-Q TOF MS have become a powerful tool for highly sensitive detection of peptides and peptide sequencing in biology. ${ }^{14,15)}$ In the studies of venom peptides of wasps, ${ }^{16,17)}$ spiders, ${ }^{18,19)}$ and scorpions, ${ }^{19)}$ these analytical approaches have been successfully applied to provide a peptide map in the venom. The peptide mapping is advantageous to explore novel peptides in the crude venom in a facile, rapid, and highly sensitive manner. ${ }^{20}$ The peptide mapping of the crude venom sample of Polistes rothneyi iwatai revealed the presence of novel peptides $(\mathrm{m} / \mathrm{z} 1565)$ and the known wasp kinins by using only a small amount of the crude venom sample provided by a facile pre-treatment of the venom (Fig. 1).

Purification of the crude venom gave six peptide fractions, among them, four peptides including three novel mastoparan analogs and one protonectin analog. According to the sequence homologies of P-3, 4, and 5 to that of mastoparan, we named P-3, P-4, and P-5 as polistes-mastoparan-R (Pm-R) $1-3$, respectively. P-6 shows a sequence homology to a histamine-releasing peptide, protonectin ${ }^{25,26)}$ and polybia$\left.\mathrm{CP},{ }^{27}\right)$ isolated from Brazilian social wasps Protonectarina sylveirae, Agelaia pallipes pallipes or Polybia paulista. Thus, we named P-6 as polistes-protonectin.

Mastoparan isolated from Paravespula lewisii is a biologically active tetradecapeptide with the C-terminus amidated. ${ }^{6}$ Mastoparan is rich in hydrophobic amino acids such as Leu,
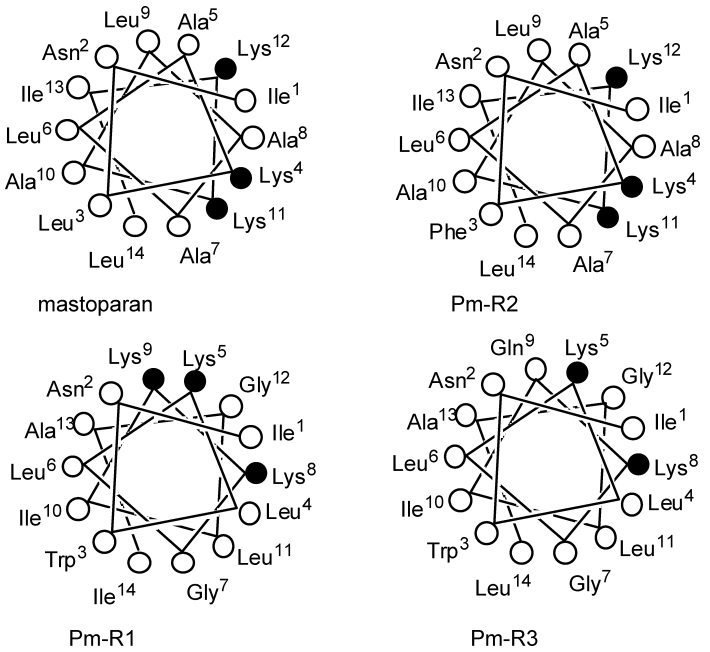

Fig. 4. Projection of the Sequences of Mastoparan and Pm-R1-3 as $\alpha$ Helical Wheels

Ile, and Ala, and basic amino acids such as Lys. ${ }^{2,3,6)}$ Many mastoparan analogs have been isolated from the venom of hornets, yellow jackets, and paper wasps (Vespidae) as well as solitary wasps. ${ }^{28,29)}$ Structures of masoparans and protonectine isolated from social wasps are depicted in Fig. 3. Mastoparan and its analogs isolated from the venom of Vespinae commonly possess Lys residues at the 4, 11, and 12 positions (type A). In contrast, the mastoparans isolated from the venom of Polistinae are usually preserved Trp and Lys residues at the 3 and 5 position (type B) except for protonectarina mastoparan, ${ }^{25)}$ protopolybia MPII, ${ }^{30)}$ and Pm-R2. Pm$\mathrm{R} 2$ is the first example of a type A analog from the venom of Asian Polistinae. Polistes-protonectin shows a high sequence homology to a histamine-releasing peptide, protonectin, isolated from Brazilian social wasps Protonectarina sylveirae ${ }^{25}$ ) and Agelaia pallipes pallipes, ${ }^{26)}$ and polybia-CP isolated from Polybia paulista. ${ }^{27)}$ Protonectin has a partial sequence homology with bombolitin-V (bumble bee, Megabombus pennsylvanicus) and Ves-CP-T (Vespa tropica) known as mast cell degranulating and chemotactic peptides. Polistesprotonectin is the first example of a protonectin analog isolated from the venom of Asian Polistinae. The above results have chemotaxonomical interests in terms of the distribution of protonectins and its related peptides in the venom of wasps and bumblebees over the region and species.

Pm-R1, 2, and 3 showed histamine-releasing activities from rat mast cells. Pm-R2 $\left(\mathrm{EC}_{50}=0.26 \mu \mathrm{M}\right)$ was compatible with that of mastoparan $\left(\mathrm{EC}_{50}=0.24 \mu \mathrm{M}\right)$ due to the high homology of mastoparan (type A). In contrast, Pm-R1 and 3 $\left(\mathrm{EC}_{50}=0.09,0.16 \mu \mathrm{M}\right)$ exhibited higher potency than that of mastoparan. Mastoparans are found to be amphiphilic when their sequences were depicted in the $\alpha$-helical projections of Schiffer and Edmundson (Fig. 4). ${ }^{31)}$ In this helical structure, hydrophobic residues and the cationic charges are separately located in one region of the molecule. The amphiphilic nature plays an important role in the biological activities. PmR1 and mastoparan differ in the position of the Lys residues. In this case, the Lys residues are densely localized in the middle of the $\alpha$-helical structure of Pm-R. The dense localization of the Lys residues may contribute to enhancing the potency of their histamine-releasing activities. It is notewor- 
thy that histamine-releasing activities of Pm-R3 are compatible with that of mastoparan, although Pm-R2 has only two Lys residues.

Hemolytic activity test of Pm-R1-3, polistes-protonectin, and mastoparan against sheep blood cells indicated that heamolytic activity of the novel peptides were more potent than that of mastoparan. Among them, hemolytic activity of polistes-protonectin was significant. Previously, Dohtsu et al. compared hemolytic activities of mastoparan and protonectin and found that protonectin exhibited about a half potency of that of mastoparan. ${ }^{25)}$ Comparison of the previous data with our results indicated that hemolytic activity of polistes-protonectin is more potent than that of protonectin.

In conclusion, we have found four novel peptides in the venom of Polistes rothneyi iwatai. Biological activities of mastoparan and Pm-R1 were found to be more potent than the previous venom peptide analogs. These results would provide new insight into the structure-activity relationship studies of this class of biologically active peptides.

Acknowledgements We are grateful to Dr. K. Gokon at Tohoku Gakuin University, Mr. Y. Fukuda at Suntory Biomedical Research Ltd., and Professor H. Okada at the Plant Museum of Osaka City University for valuable discussions. This study was supported by the Research for the Future Program from the Japan Society for the Promotion of Science (JSPS 99L01204).

\section{REFERENCES}

1) Habermann E., Science, 177, 314-322 (1972).

2) Nakajima T., "Handbook of Natural Toxins," Vol. 2, ed. by Tu A. T., Mercel Dekker, Inc., New York, 1984, pp. 109-133.

3) Nakajima T., "Venoms of the Hymenoptera," ed. by Piek T., Academic Press, Orland, 1986, pp. 309-327.

4) Nakajima T., Yakugaku Zasshi, 113, 114-132 (1993).

5) Haux V. P., Hoppe-Seyler's Z. Physiol. Chem., 350, 536-546 (1969).

6) Hirai Y., Yasuhara T., Yoshida H., Nakajima T., Fujino M., Kitada C., Chem. Pharm. Bull., 27, 1942-1944 (1979).

7) Piek T., “Animal Toxins," eds. by Rochat H., Martin-Eauclaire M. F., Birkhäuser Verlag, Basel, 1999, pp. 99-115.

8) Kishimura H., Yasuhara T., Yoshida H., Nakajima T., Chem. Pharm. Bull., 24, 2896-2897 (1976).

9) Udenfriend S., Nakajima T., Pisano J. J., Proc. Int. Cong. Biochem., 7th, abstract VII-4, 1967, p. 501.

10) Habermann E., Kowallek H., Hoppe-Seyler's Z. Physiol. Chem., 351, 884-890 (1970).

11) Haux V. P., Sawerthal H., Habermann E., Hoppe-Seyler's Z. Physiol. Chem., 348, 737-738 (1967).

12) Hirai Y., Ueno Y., Yasuhara T., Yoshida H., Nakajima T., Biomed. Res., 1, 185-187 (1980).

13) Watanabe M., Yasuhara T., Nakajima T., "Animal, Plant and Microbial Toxins," Vol. 2, ed. by Ohsaka A., Plenum, New York, 1976, pp. 105112.

14) Kinter M., Sherman N. E., "Protein Sequencing and Identification using Tandem Mass Spectrometry," eds. by Desiderio D. M., Nibbering M. M., Wiley-Interscience, A John Wiley \& Sons, Inc., Publication, New York, 2000.

15) Takayama M., Tsugita A., "Mass Spectrometry in Protein Study. In New Advances in Analytical Chemistry," Vol. 3, ed. by Rahman A., Taylor \& Francis, London, 2002, pp. 163-210.

16) Konno K., Palma M. S., Hirata I. Y., Juliano M. A., Juliano L., Yasuhara Y., Toxicon, 40, 309-312 (2002).

17) Hisada M., Konno K., Itagaki Y., Naoki H., Nakajima T., Rapid Commun. Mass Spectrom., 16, 1040-1048 (2002).

18) Corzo G., Escoubas P., Cell. Mol. Life Sci., 60, 2409-2426 (2003).

19) Naoki H., Dai L., Nakajima T., J. Mass Spectrom. Soc. Jpn., 51, $91-$ 95 (2003).

20) Nakajima T., Naoki H., Corzo G., Dai L., Hisada M., Escoubas P., Yamaji N., Nagai H., Yasuda A., Andrianstiferana M., Haup J., Ohsiro N., J. Toxicol. Toxin Rev., 22, 509-520 (2003).

21) Argiolas A., Pisano J., J. Biol. Chem., 260, 1437-1444 (1985).

22) Nagai H., Takuwa K., Nakao M., Ito E., Miyake M., Noda M., Nakajima T., Biochem. Biophys. Res. Commun., 275, 582-588 (2000).

23) Murata K., Shinada T., Ohfune Y., Hisada M., Naoki H., Nakajima T., 44rd Tennen Yuki Kagobutu Toronkai, abstract, 2002, pp. 301-306.

24) Hisada M., Satake H., Masuda K., Aoyama M., Murata K., Shinada T., Iwashita T., Ohfune Y., Nakajima T., Biochem. Biophys. Res. Commun., 330, 1048-1054 (2005).

25) Dohtsu K., Okumura K., Hagiwara K., Palma M. S., Nakajima T., Natural Toxins, 1, 271-276 (1993).

26) Mendes M. A., de Souza B. M., Marques M. B., Palma M. S., Toxicon, 44, 67-74 (2004).

27) Souza B. M., Mendes M. A., Santos L. D., Marques M. R., Cesar L. M. M., Almeida R. N. A., Pagnocca F. C., Konno, K., Palma M. S., Peptides, 26, 2157-2164 (2005).

28) Sforca M. L., Oyama S., Jr., Canduri F., Lorenzi C. C. B., Pertinhez T. A., Konno K., Souza B. M., Palma M. S., Ruggiero Neto J., Azevedo, W. F., Jr., Spisni A., Biochemistry, 43, 5608-5617 (2004).

29) Konno K., Hisada M., Naoki H., Itagaki Y., Kawai N., Miwa A., Yasuhara T., Morimoto Y., Nakata Y., Toxicon, 38, 1505-1515 (2000).

30) Mendes M. A., de Souza B. M., Marques M. B., Palma M. S., Toxicon, 45, 101-106 (2005).

31) Schiffer M., Edmundson A. B., Biophys. J., 7, 121-135 (1967). 